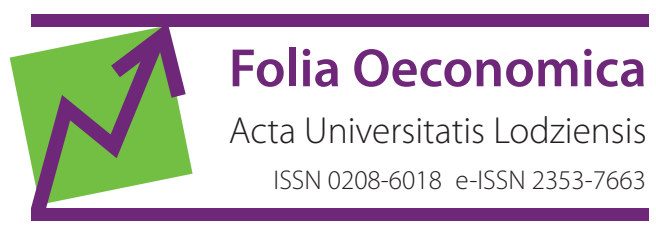

www.czasopisma.uni.lodz.pl/foe/

6(345) 2019

DOI: http://dx.doi.org/10.18778/0208-6018.345.05

\author{
Aleksandra Pieloch-Babiarz \\ University of Łódź, Faculty of Economics and Sociology, Department of International Finance \\ and Investments, aleksandra.pieloch@uni.lodz.pl
}

\title{
Diversified Ownership Structure and Dividend Pay-outs of Publicly Traded Companies
}

\begin{abstract}
The aim of this article is to identify and characterise the relationship between the ownership structure and dividend pay-out of listed companies. The research hypothesis states that along with an increase in a degree of ownership concentration both the propensity to pay a dividend and its amount increase. The research has been conducted on a group of 354 non-financial companies listed on the Warsaw Stock Exchange. The basic research method is the analysis of logistic and tobit regression. The research shows that along with an increase in the complexity of the ownership structure, the share of the State Treasury, institutional investors and board members, decisions on dividend pay-out are made more often, and the amount of dividend is higher. Examining the degree of ownership concentration expressed by the Herfindahl-Hirschman index, diversified results have been obtained. An estimation of some regression models shows that stronger ownership concentration favours the decision to pay a dividend (dividends are paid out more frequently), however, as a degree of ownership concentration increases, a decrease in the amount of dividend is observed. The research results presented in this article are a supplement to the existing analyses carried out on the global markets and an extension of the existing research conducted on the companies listed on the Warsaw Stock Exchange.
\end{abstract}

Keywords: dividend policy, ownership structure, managerial ownership, institutional ownership, state ownership, the WSE

JEL: G11, G18, G35 


\section{Introduction}

A dividend policy concerns the division of net profit into the part left in the company (which is usually used for financing investment projects) and the part which is transferred to the shareholders as a dividend (enabling them to achieve investment returns). The decision about the amount of retained earnings and dividend is considered as a strategic decision in the area of corporate finance. This decision is influenced by many different factors.

Among the determinants of dividend policy are microeconomic, macroeconomic and behavioural factors. Many academic studies refer to macroeconomic factors, such as: economic situation, legal and monetary system, tax policy, and inflation rate (Eije, Megginson, 2008: 363; Jacob, Jacob, 2013: 30). Increasingly, behavioural (psychological) factors are included in the research. Among them, one should indicate preferences of stock market investors (French, Varson, Moon, 2005: 361), dividend premium (Baker, Wurgler, 2004: 271), and investors' expectations regarding the amount of future dividends (Fisher, Statman, 2000: 72). However, most studies concern microeconomic determinants of dividend policy, such as profitability and financial liquidity, the level of indebtedness, maturity of the company, investment opportunities, the company's size (DeAngelo, DeAngelo, 2007: 11), and the ownership structure. The analysis of global studies on the impact of the ownership structure on dividend payment does not provide unambiguous conclusions ${ }^{1}$. Moreover, this issue is subject to few preliminary studies conducted on the WSE (Wypych, 2015: 783; Kaźmierska-Jóźwiak, 2016: 171; Pieloch-Babiarz, 2017: 29). Therefore, it is considered reasonable to undertake scientific research in this area.

The aim of this paper is to identify and characterise the relationship between the ownership structure and dividend pay-out of listed companies. This objective is important not only from the point of view of the implementation of dividend policy in companies, but it is also significant in the context of market value of the company and shareholder value. The aim is accomplished by an empirical verification of the research hypothesis which states that along with an increase in a degree of ownership concentration both the propensity to pay a dividend and its amount increase.

The remainder of this article is organised as follows. Section 2 is focused on a brief literature review. Section 3 details research methodology. Section 4 describes the research sample. Section 5 presents the results of empirical research and discusses them. Section 6 highlights the main research findings.

1 Compare, for example, the research results of Mancinelli and Ozkan (2006: 265) with Khan (2006: 172) or Smith, Pennathur and Marciniak (2017: 38) with Florackis, Kanas and Kostakis (2015: 783). 


\section{Ownership structure as a determinant of dividend policy - literature review}

The ownership structure is defined as a number of shares which are held by different groups of shareholders (Wypych, 2015: 785). Depending on the purpose of research, shareholders of publicly traded companies can be classified according to the criteria presented in Table 1.

According to the agency theory, the ownership structure can affect the conflict between shareholders and managers. Shareholders (principals) by conclusion of a contract with managers (agents) delegate the right to manage the company. Both shareholders and managers strive to maximise their own benefits, but their goals differ from each other. The main goal of shareholders is to increase the market value of shares and receive a dividend, while managers strive to increase their income in various forms, including a salary increase and perks (Bohdanowicz, 2016: 19). This difference of interests leads to a conflict and results in an increase in agency costs, especially when managers inefficiently invest free cash flows. It is said that dividend pay-out makes free cash flows decrease and, in this way, helps to reduce the agency costs (Grullon et al., 2005: 1659). What is more, one of the ways of bringing the goals of owners and managers closer is to increase the share of managers in the ownership structure (Bohdanowicz, 2016: 19). Some studies show that if managers receive shares of the company, they start to behave like shareholders and adopt shareholders' goals, which results, among others, in higher dividend pay-out (Lace, Bistrova, Kozlovskis, 2013: 259; Smith, Pennathur, Marciniak, 2017: 38). In turn, Florackis, Kanas and Kostakis (2015: 783) prove the existence of a negative relationship between managerial ownership and a dividend when managers have relatively few shares. However, this negative relationship turns into a positive one when managerial ownership is very high.

As studies show, the State Treasury and institutional investors are those shareholders that try to achieve the highest return on investment. Therefore, they strive to receive a dividend (Smith, Pennathur, Marciniak, 2017: 38). It is known that institutional investors usually have a great capital involvement in the company, so they can control managers and decide about dividend pay-outs. Therefore, most studies show a positive relationship between institutional ownership and dividend pay-out (Short, Zhang, Keasey, 2002: 105). What is more, similar research results are observed for the State Treasury which is a dominant shareholder. The State Treasury has large capital needs, so it will strive to be paid out dividend (Liljeblom, Maury, 2016: 2414). In turn, a real influence of minority shareholders on the decision making process in the company is limited, so if the free float is higher the propensity to pay a dividend is lower (Pieloch-Babiarz, 2017: 29). 
Table 1. Chosen criteria for classification of shareholders of publicly traded company

\begin{tabular}{|c|c|c|}
\hline $\begin{array}{c}\text { Classification } \\
\text { criteria }\end{array}$ & \begin{tabular}{|c|} 
Types \\
of shareholders
\end{tabular} & Characteristics of shareholders \\
\hline $\begin{array}{l}\text { Degree } \\
\text { of involvement } \\
\text { in the } \\
\text { company's } \\
\text { affairs }\end{array}$ & $\begin{array}{l}\text { Active and pas- } \\
\text { sive investors }\end{array}$ & $\begin{array}{l}\text { 1. Market context (Adamska, 2012: 37): } \\
\text { Active investors constantly seek opportunities to effectively } \\
\text { involve their capital (they often buy and sell shares of com- } \\
\text { panies), while passive investors implement a buy and hold } \\
\text { investment strategy. } \\
\text { 2. Corporate governance context (Adamska, 2012: } 37 \text { ): } \\
\text { Active investors are involved in the company's affairs (in- } \\
\text { cluding the participation in general meetings, taking part } \\
\text { in the decision-making process and electing the board mem- } \\
\text { bers and the supervisory council), while passive investors } \\
\text { are not involved in this regard. }\end{array}$ \\
\hline $\begin{array}{l}\text { Number } \\
\text { of shares and } \\
\text { possibilities } \\
\text { to influence } \\
\text { decisions } \\
\text { made at the } \\
\text { general } \\
\text { meeting }\end{array}$ & \begin{tabular}{|l|} 
Shareholder \\
holding a con- \\
trolling share, \\
dominant share- \\
holder, signifi- \\
cant shareholder, \\
minority share- \\
holder, small \\
shareholder
\end{tabular} & $\begin{array}{l}\text { A shareholder holding a controlling share has more than } \\
50 \% \text { share in the total number of votes. } \\
\text { A dominant shareholder has less than } 50 \% \text { of the total num- } \\
\text { ber of votes, but - due to the arrangement of votes - at the } \\
\text { general meeting his/her vote is decisive. } \\
\text { A significant shareholder has a big influence on decisions } \\
\text { in the company, but cannot decide alone. } \\
\text { A minority shareholder holds a block of shares with less than } \\
5 \% \text { of votes at the general meeting and therefore has no great } \\
\text { influence on the company. } \\
\text { A small shareholder usually remains unidentified and does } \\
\text { not participate in making decisions at general meetings } \\
\text { (Adamska, 2012: 40) }\end{array}$ \\
\hline $\begin{array}{l}\text { Information } \\
\text { obligation }\end{array}$ & $\begin{array}{l}\text { Notified investor } \\
\text { and free float }\end{array}$ & $\begin{array}{l}\text { Shareholders with at least } 5 \% \text { of votes are defined as notified } \\
\text { shareholders, while the others are called free float (Wawry- } \\
\text { szuk-Misztal, 2016: 144). }\end{array}$ \\
\hline $\begin{array}{l}\text { Identity } \\
\text { of investors }\end{array}$ & \begin{tabular}{|l|} 
Company \\
(domestic and \\
foreign), institu- \\
tional investor, \\
individual inves- \\
tor, managers, \\
the State \\
Treasury
\end{tabular} & $\begin{array}{l}\text { Such a classification of investors is usually found in the aca- } \\
\text { demic literature (compare: Aluchna, 2007: 281; Lace, Bistro- } \\
\text { va, Kozlovskis, 2013: 261; Wypych, 2015: 786). } \\
\text { A company is a legal entity that is not an institutional } \\
\text { investor. } \\
\text { An institutional investor is an entity professionally involved } \\
\text { in investing capital entrusted by third parties. It can be, for } \\
\text { example, a bank, an insurance company, a pension or invest- } \\
\text { ment fund (Dębski, 2007: 550). } \\
\text { An individual investor is a natural person (who is not the } \\
\text { company's manager) investing his/her own capital. The State } \\
\text { Treasury is an institution representing the state as the owner } \\
\text { of state property in civil-legal relations. }\end{array}$ \\
\hline
\end{tabular}

Source: own elaboration

When considering dividend pay-out, ownership concentration should be taken into account. Some studies show that an increase in ownership concentration results in a higher dividend. It is explained by the strong control and strong impact 
of the dominant shareholder on achieving the shareholders' goals, including dividend payment (Mancinelli, Ozkan, 2006: 265). In contrast, Khan (2006: 172-173) shows the existence of negative links between ownership concentration and dividend pay-out. He argues that in those companies in which ownership is strongly concentrated, earnings are usually left as retained earnings and used to improve the company's performance. This proves that dominant shareholders protect their own interest at the cost of minority shareholders.

\section{Research methodology}

Empirical research aimed at identifying and characterising the relationship between ownership concentration and dividend pay-out is conducted on a group of 354 companies listed on the Warsaw Stock Exchange in 2016. The condition for including the company in the research sample is running business activities in one of 35 economic sectors. Due to the nature of this study, companies from the financial sector are excluded from the sample. An empirical verification of the hypothesis is carried out in a few stages.

First, the dependant, independent and control variables have been chosen. They are used to investigate the character of links between ownership concentration and dividend pay-out. There are two dependent variables $(D I V, D P R)$, five independent variables (INSTIT, MANAG, STATE, FFLOAT, HHI) and four control variables $(R O A, C R, \ln T C, G R O W T H)$. These variables are presented in Table 2.

\section{Table 2. Characteristics of the research variables}

\begin{tabular}{|l|l|}
\hline \multicolumn{1}{|c|}{ Symbol } & \multicolumn{1}{c|}{ Description of the research variable } \\
\hline$D I V$ & $\begin{array}{l}\text { A binary variable adopting the value of } 1 \text { if the company pays out a dividend in the } \\
\text { year } t \text {, otherwise adopting the value of } 0 .\end{array}$ \\
\hline$D P R$ & $\begin{array}{l}\text { Dividend pay-out ratio in the year } t \text { calculated as the relationship between the } \\
\text { dividend per share and earnings per share, i.e. DPS/EPS. }\end{array}$ \\
\hline INSTIT & $\begin{array}{l}\text { Share of votes of institutional investors in the total number of votes } \\
\text { in the year } t-1 .\end{array}$ \\
\hline MANAG & Share of votes of managers in the total number of votes in the year $t-1$. \\
\hline STATE & Share of votes of the State Treasury in the total number of votes in the year $t-1$. \\
\hline FFLOAT & Share of votes of the free float in the total number of votes in the year $t-1$. \\
\hline HHI & $\begin{array}{l}\text { The Herfindahl-Hirschman index which is a measure of ownership concentration } \\
\text { in the year } t-1 \text {. It is calculated by squaring the share of votes of each notified } \\
\text { investor and then summing up the results. This index ranges from } 0 \text { to } 1 .\end{array}$ \\
\hline ROA & $\begin{array}{l}\text { Return on assets in the year } t-1 \text { calculated as a relationship between earnings } \\
\text { after tax in the year } t-1 \text { and total assets of the company in the year } t-1 .\end{array}$ \\
\hline$C R$ & $\begin{array}{l}\text { Current ratio in the year } t-1 \text { calculated as the relationship between the current } \\
\text { assets in the year } t-1 \text { and current liabilities in the year } t-1 .\end{array}$ \\
\hline
\end{tabular}




\begin{tabular}{|l|l|}
\hline \multicolumn{1}{|c|}{ Symbol } & \multicolumn{1}{c|}{ Description of the research variable } \\
\hline $\ln T C$ & $\begin{array}{l}\text { Size of the company measured by the natural logarithm of the total capital } \\
\text { in the year } t-1 .\end{array}$ \\
\hline GROWTH & $\begin{array}{l}\text { Opportunities of growth measured by the relationship between the sum } \\
\text { of capitalisation and debt to total assets (Adjaoud, Hermassi, 2017: } 96 \text { ). }\end{array}$ \\
\hline
\end{tabular}

Source: own study

Next, the analysis of nature and strength of the links between dividend pay-out and the share of votes of diverse groups of shareholders has been conducted. The impact of diversity of the ownership structure on the probability of dividend pay-out has been tested using the cross-sectional logit model described by the following formula (Kufel, 2009: 138):

$$
Y=\left\{\begin{array}{l}
1 \text { for } Y^{*}>0 \\
0 \text { for } Y^{*}=0
\end{array} \text {, when } Y^{*}=\ln \frac{P_{i}}{1-P_{i}}=\beta_{0}+\sum_{i=1}^{k} \beta_{i} X_{i}+\varepsilon_{i},\right.
$$

where:

$\beta_{i}, i=0, \ldots, k$ - regression coefficients,

$X_{1}, X_{2}, \ldots, X_{k}$ - independent variables presented in Table 2,

$P_{i}$ - conditional probability that the dependent variable $D I V$ is equal to 1 for the values of independent variables $X_{1}, X_{2}, \ldots, X_{k}$.

Then, McFadden's $p$ seudo- $R^{2}$ coefficient has been calculated. It is given by the following formula (Stanisz, 2007: 251):

$$
R_{\text {MCFadden }}^{2}=1-\frac{\ln L_{p}}{\ln L_{0}}
$$

where:

$\ln L_{p}$ - the maximised likelihood for the model with all predictors, $\ln L_{0}^{p}$ - the maximised likelihood for the model without any predictor.

In turn, to recognise the links between ownership concentration and the amount of dividend pay-out, the tobit model has been used (Kufel, 2009: 146):

$$
Y=\left\{\begin{array}{l}
Y^{*} \text { for } Y^{*}>0 \\
0 \text { for } Y^{*}=0
\end{array}, \text { when } Y^{*}=\beta_{0}+\sum_{i=1}^{k} \beta_{i} X_{i}+\varepsilon_{i},\right.
$$

where:

$Y$ - dependent variable $D P R$ (dividend pay-out ratio),

the other designations as above.

The research has been extended by the analysis of descriptive statistics, post-hoc Tukey's test and the correlation analysis using Pearson's correlation coefficient. This analysis is aimed not only at identifying the impact of the examined 
variables on the amount of dividend but also - by investigating the strength of links between the independent variables - it allows us to maintain the correctness of research methods and makes it possible to choose for the models such independent variables which are characterised by relatively the weakest mutual correlation. Thus, six logit and tobit models have been estimated (see Table 3).

Table 3. Models used for empirical verification of the research hypothesis

\begin{tabular}{|c|c|}
\hline Model & Description and form of regression model \\
\hline \multirow[t]{2}{*}{ Model 1} & $\begin{array}{l}\text { Model constructed using only control variables that characterise the chosen aspects } \\
\text { of financial standing of the company. }\end{array}$ \\
\hline & $Y^{*}=\beta_{0}+\beta_{1} R O A_{i}+\beta_{2} C R_{i}+\beta_{3} \ln T C_{i}+\beta_{4} G R O W T H_{i}+\varepsilon_{i}$ \\
\hline \multirow[t]{2}{*}{ Model 2} & $\begin{array}{l}\text { Construction of this model is based only on the explanatory variables describing } \\
\text { the ownership structure of the company. }\end{array}$ \\
\hline & $Y^{*}=\beta_{0}+\beta_{1} I_{N S T I T}+\beta_{2} M_{A N A G_{i}}+\beta_{3} \operatorname{STATE}_{i}+\beta_{4} F F L O A T_{i}+\beta_{5} H H I_{i}+\varepsilon_{i}$ (5) \\
\hline \multirow[t]{2}{*}{ Model 3} & $\begin{array}{l}\text { Model contains all nine explanatory variables, i.e. the variables characterising } \\
\text { the ownership structure as well as the control variables. }\end{array}$ \\
\hline & $\begin{array}{l}Y^{*}=\beta_{0}+\beta_{1} I N S T I T_{i}+\beta_{2} \text { MANAG }_{i}+\beta_{3} \text { STATE }_{i}+\beta_{4} \text { FFLOAT }_{i}+ \\
+\beta_{5} H_{i}+\beta_{6} \text { ROA }_{i}+\beta_{7} C R_{i}+\beta_{8} \ln T C_{i}+\beta_{9} \text { SROWTH }_{i}+\varepsilon_{i}\end{array}$ \\
\hline \multirow[t]{2}{*}{ Model 4} & $\begin{array}{l}\text { Adjustment of Model } 3 \text { which consists in removing from the model both the variable } \\
H H I \text { (being the variable strongly correlated with the variable FFLOAT) and the } \\
\text { control variables } C R \text { and GROWTH (which in the estimated Model } 3 \text { proved to be not } \\
\text { statistically significant). }\end{array}$ \\
\hline & $\begin{array}{l}Y^{*}=\beta_{0}+\beta_{1} I N S T I T_{i}+\beta_{2} \text { MANAG }_{i}+\beta_{3} \text { STATE }_{i}+ \\
+\beta_{4} \text { FFLOAT }_{i}+\beta_{5} \text { ROA }_{i}+\beta_{6} \ln T C_{i}+\varepsilon_{i}\end{array}$ \\
\hline \multirow[t]{2}{*}{ Model 5} & $\begin{array}{l}\text { In this model, the variable FFLOAT from Model } 4 \text { is replaced by the variable } H H I \\
\text { (the most correlated variable), the other variables are the same as in Model } 4 .\end{array}$ \\
\hline & $\begin{array}{l}Y^{*}=\beta_{0}+\beta_{1} \text { INSTIT }_{i}+\beta_{2} \text { MANAG }_{i}+\beta_{3} \text { STATE }_{i}+ \\
+\beta_{4} H H I_{i}+\beta_{5} \text { ROA }_{i}+\beta_{6} \ln T C_{i}+\varepsilon_{i}\end{array}$ \\
\hline \multirow[t]{2}{*}{ Model 6} & Model constructed by the gradual elimination of statistically insignificant variables. \\
\hline & $\begin{array}{l}Y^{*}=\beta_{0}+\beta_{1} I N S T I T_{i}+\beta_{2} \text { MANAG }_{i}+\beta_{3} \text { STATE }_{i}+ \\
+\beta_{4} \text { FFLOAT }_{i}+\beta_{5} \text { ROA }_{i}+\varepsilon_{i}\end{array}$ \\
\hline
\end{tabular}

Source: own elaboration

The empirical research has been conducted using the statistical package STATISTICA and Gretl programme. Information about the share of votes and financial data is obtained from the Notoria Serwis database and InfoStrefa.com portal. 


\section{Analysis of the research sample}

The preliminary analysis of the research sample shows that in $20.06 \%$ of companies the free float dominates. In the majority of the analysed companies, i.e. in 283 cases, at least $50 \%$ of shares is held by so-called notified investors (i.e. shareholders having at least $5 \%$ of votes at the general meeting). Among them dominate companies in which most votes belong to so-called non-financial investors $(30.51 \%$ of the surveyed companies), as well as individual investors (17.23\% of the analysed cases). Managerial ownership dominates in $15.54 \%$ of companies, while institutional ownership in $12.71 \%$. In turn, the State Treasury has the greatest number of votes in $3.95 \%$ of the surveyed companies (see Figure 1).

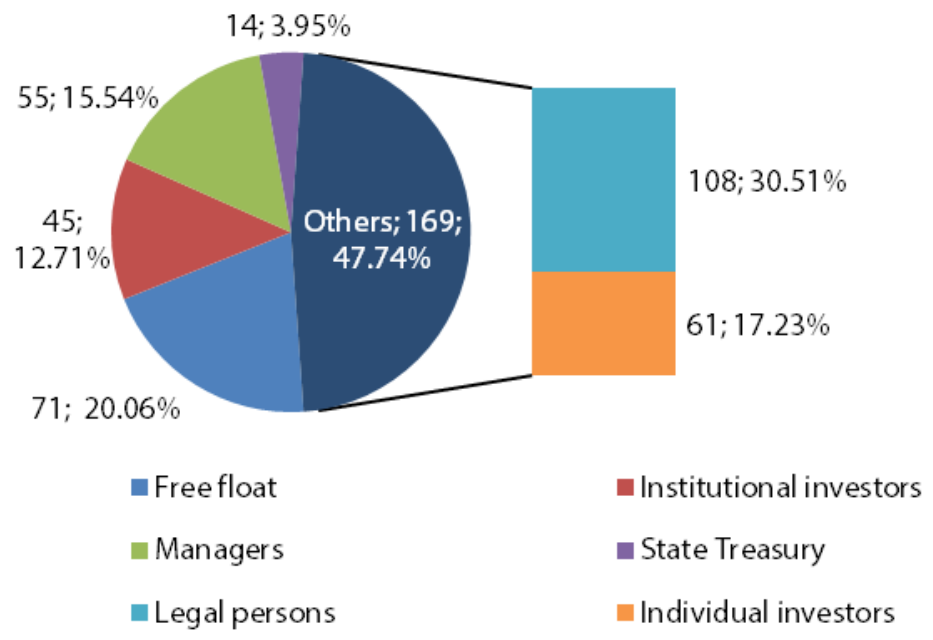

Figure 1. Number and share of the surveyed companies in relation to ownership concentration Source: own study based on the data collected from Notoria Serwis

The greatest average values of the dividend pay-out ratio are observed for the companies in which institutional investors possess the majority of votes at the general meeting. These companies pay out on average $67.7 \%$ of earnings after tax from the previous financial year. Moreover, high dividends are also observed in companies in which the State Treasury is a dominant shareholder. In this case, the average dividend pay-out ratio is at $31.8 \%$. In the companies in which the largest share of votes belongs to the board members, the average amount of dividend accounts for $28.4 \%$ of earnings, and in the case of free float, it is equal to $16.6 \%$. What is more, the analysis of significance of differences in the average value of the dividend pay-out ratio carried out taking into account different groups of owners having the largest share of votes shows that the companies differ significantly in terms of the amount of dividend pay-out. Significantly statistical differences are 
observed in the case of companies in which an institutional investor and managers dominate (statistical significance at the level of $\alpha=0.01$ ), as well as in companies in which an institutional investor and the free float dominate (statistical significance at the level of $\alpha=0.05$ ), see Table 4 .

Table 4. The results of post-hoc Tukey's test for the average value of dividend pay-out ratio for diverse groups of shareholders having the greatest share of votes at the general meeting

\begin{tabular}{|l|c|c|c|c|}
\hline \multicolumn{1}{|c|}{ Specification } & INSTIT & MANAG & STATE & FFLOAT \\
\hline \multicolumn{5}{|c|}{ The average value of DPR } \\
\hline & 0.627 & 0.284 & 0.318 & 0.166 \\
\hline The post-hoc Tukey's test $(\boldsymbol{p}$-value) \\
\hline INSTIT & - & 0.045 & 0.410 & 0.001 \\
\hline MANAG & 0.045 & - & 0.998 & 0.747 \\
\hline STATE & 0.410 & 0.998 & - & 0.858 \\
\hline FFLOAT & 0.001 & 0.747 & 0.858 & - \\
\hline
\end{tabular}

Source: own elaboration based on the data collected from Notoria Serwis

Table 5 presents descriptive statistics. The results of analysis show that the average dividend pay-out accounts for $31.9 \%$ of earnings after tax generated in the last fiscal year. The median of dividend pay-out ratio is at $0.0 \%$, which results from the dominance of companies not paying out a dividend (dividend companies accounted for $35.9 \%$ of the surveyed companies). In turn, every fourth company pays out a dividend at the level of at least $45.8 \%$ of earnings. What is more, the institutional investor possesses on average $11.2 \%$ of votes. In half of the companies, institutional investors hold less than $5.3 \%$ of votes at the general meeting of shareholders, and in every fourth company at least $18.1 \%$. The average managerial ownership accounts for $9.2 \%$. In at least half of the companies, the board members have no shares, and in $25 \%$ of the companies this share is higher than $12.2 \%$. The greatest share of managers in the structure of votes is $57.8 \%$. Considering the state ownership, it should be noted that the average share of votes held by the State Treasury is $2.2 \%$ (in at least $75 \%$ of the surveyed companies, the State Treasury does not hold any shares), and the largest share of state ownership amounts to $72.3 \%$. On the other hand, the average value of voting share of free float is $35.2 \%$, and in every fourth company this share accounts for at least $46.8 \%$. In turn, the average value of the Herfindahl-Hirschman index is at 0.268 , the minimum is at 0.034 and the maximum is at 0.703 .

Table 5. Descriptive statistics $(N=354)$

\begin{tabular}{|l|c|c|c|c|c|c|c|}
\hline Specification & Mean & S. D. & Min. & Q1 & Median & Q2 & Max. \\
\hline$D P R$ & 0.319 & 0.741 & 0.000 & 0.000 & 0.000 & 0.458 & 6.795 \\
\hline$I N S T I T$ & 0.112 & 0.142 & 0.000 & 0.000 & 0.053 & 0.181 & 0.464 \\
\hline
\end{tabular}




\begin{tabular}{|l|c|c|c|c|c|c|c|}
\hline Specification & Mean & S. D. & Min. & Q1 & Median & Q2 & Max. \\
\hline MANAG & 0.092 & 0.173 & 0.000 & 0.000 & 0.000 & 0.122 & 0.578 \\
\hline STATE & 0.022 & 0.105 & 0.000 & 0.000 & 0.000 & 0.000 & 0.723 \\
\hline FFLOAT & 0.352 & 0.236 & 0.000 & 0.181 & 0.312 & 0.468 & 0.980 \\
\hline HHI & 0.268 & 0.192 & 0.034 & 0.113 & 0.235 & 0.394 & 0.703 \\
\hline ROA & 0.056 & 0.048 & 0.000 & 0.018 & 0.056 & 0.068 & 0.187 \\
\hline CR & 1.961 & 2.407 & 0.000 & 0.702 & 1.314 & 2.103 & 10.649 \\
\hline $\operatorname{lnTC}$ & 12.453 & 1.367 & 10.083 & 11.515 & 12.453 & 13.240 & 15.437 \\
\hline GROWTH & 1.291 & 0.857 & 0.280 & 0.741 & 1.105 & 1.383 & 3.887 \\
\hline
\end{tabular}

Source: own study based on the data collected from Notoria Serwis and InfoStrefa.com

The surveyed companies run their business activities in different economic sectors which are characterised by specific economic conditions. This is confirmed in different values of descriptive statistics for the control variables. The average return on assets is at $5.6 \%$, the minimum is at $0.0 \%$, and the maximum is at $18.0 \%$. The average value of the current ratio is equal to 1.961 , while in every fourth company, it amounts to at least 2.103. The companies also differ in terms of company's size. The average value of the natural logarithm of total capital is 12.453 , the minimum is 10.083 , and the maximum is at 15.437. In addition, the surveyed companies also differ in terms of development opportunities. The average value of GROWTH (at 1.291) and the median value (at 1.105) indicate good investment opportunities of the analysed companies (see Table 5).

\section{Results of the empirical research}

The preliminary research on differentiation of the nature and strength of the links between ownership concentration and dividend pay-out has been conducted using Pearson's linear correlation coefficient. The survey shows the existence of a statistically significant, positive and weak relationship between the propensity to pay a dividend and the share in the ownership structure of institutional investors, managers and the State Treasury (0.202, 0.090 and 0.123 , respectively). In turn, along with an increase in the number of votes of free float, the decision on dividend is made less frequently (statistically significant value of Pearson's correlation coefficient is at -0.134). However, statistically insignificant and close to zero is the value of the correlation coefficient examining the relationship between the $H H I$ index and dividend pay-out ( -0.035$)$. In addition, the propensity to pay a dividend increases along with an increase in return on assets, liquidity, the size of the company and development opportunities (see Table 6). 


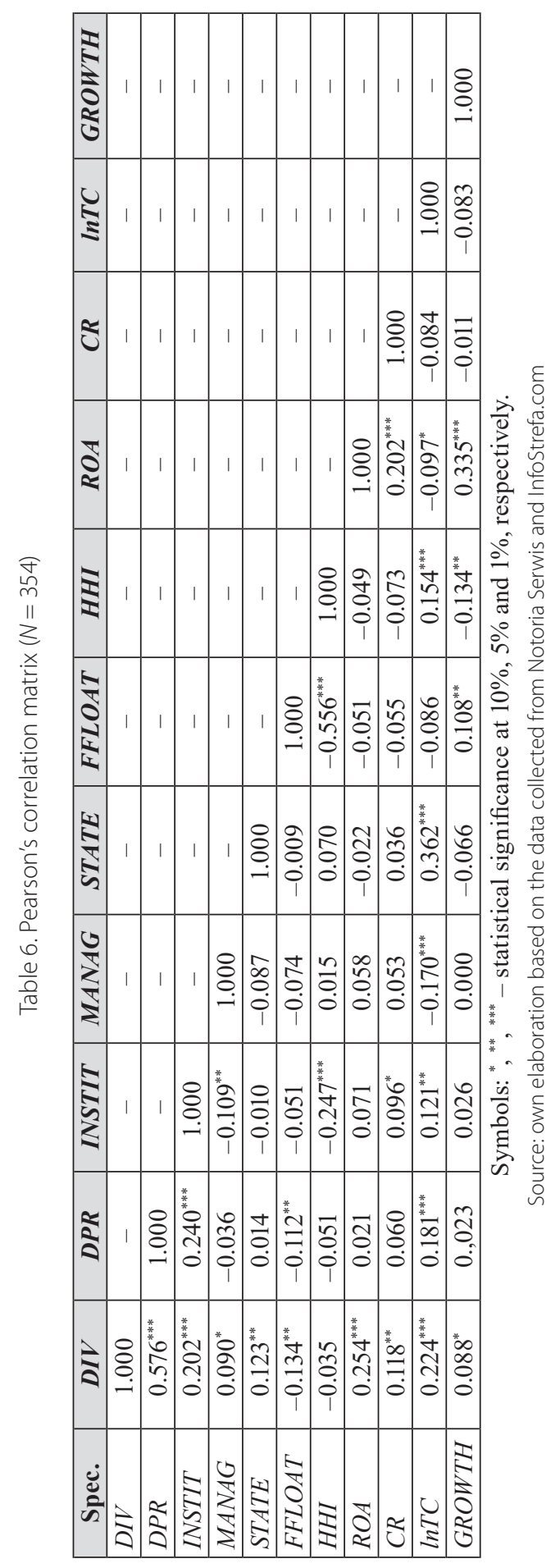


The analysis of dependencies between the ownership structure and the amount of dividend pay-out presented in Table 6 shows that along with an increase of the institutional investor's share, the companies pay out a greater part of earnings (correlation coefficient is at 0.240 ). In turn, an increase in the share of free float results in a decrease in the amount of dividend $\left(r_{y x}\right.$ at -0.112$)$. Moreover, the research shows that along with an increase in the size of the company, the amount of dividend increases (correlation coefficient at 0.181). Considering the relationship between the explanatory variables, it should be stated that the strongest correlation occurs between $H H I$ and FFLOAT. It is a negative correlation of moderate strength $(-0.556)$.

The empirical research on the links between ownership concentration and dividend pay-outs has been extended by estimating twelve regression models. First, the influence of the ownership structure on the propensity to pay a dividend is examined (logit models). Then, the influence of the ownership structure on the amount of dividend is investigated (tobit models).

The values of estimated parameters of logit models are shown in Table 7. They allow us to state that the surveyed companies more often pay a dividend $(D I V)$ if there is a higher share of institutional investors in the ownership structure. In each of five models with this variable, the value of parameter for INSTIT is positive and statistically significant at least at the significance level of $\alpha=0.05$. The values of estimated parameter for INSTIT range from 2.212 to 3.157, and in some models it is the highest value (not including the values of the parameters for the control variables). This indicates that institutional ownership has the greatest impact on dividend pay-out.

Moreover, there is observed a statistically significant relationship between managerial ownership and dividend pay-out. The values of parameter for $M A N$ $A G$ are positive and statistically significant in all five models, but slightly lower than those for INSTIT (their value ranges from 1.395 to 1.953). Therefore, it can be concluded that dividend pay-out is more frequent in the companies in which the share of board members in the ownership structure is higher. Also, the values of parameter for STATE are positive, but statistically significant only in two models (in Model 2 at 2.902 and in Model 6 at 2.917). The research results allow us to note that the increase in the state ownership positively affects the payment of dividend. In turn, the value of parameter for FFLOAT is negative in each model and ranges from -1.139 to -1.963 .Thus, along with an increase in the share of free float, less frequent dividend pay-outs are observed. What is more, if ownership concentration increases, the probability of dividend pay-out increases (the value of parameter for $H H I$ is at 12.318). The survey shows that dividend pay-out also depends on return on investment (the value of parameter for $R O A$ ranges from 0.413 to 12.318) and the size of the company (the value of parameter for $\ln T C$ is statistically significant only in Model 1, 3 and 4 and ranges from 0.396 to 0.435). Along with the increase in their values, more frequent dividend payments are expected. The values of estimated parameter for the other control variables are not statistically significant (see Table 7). 


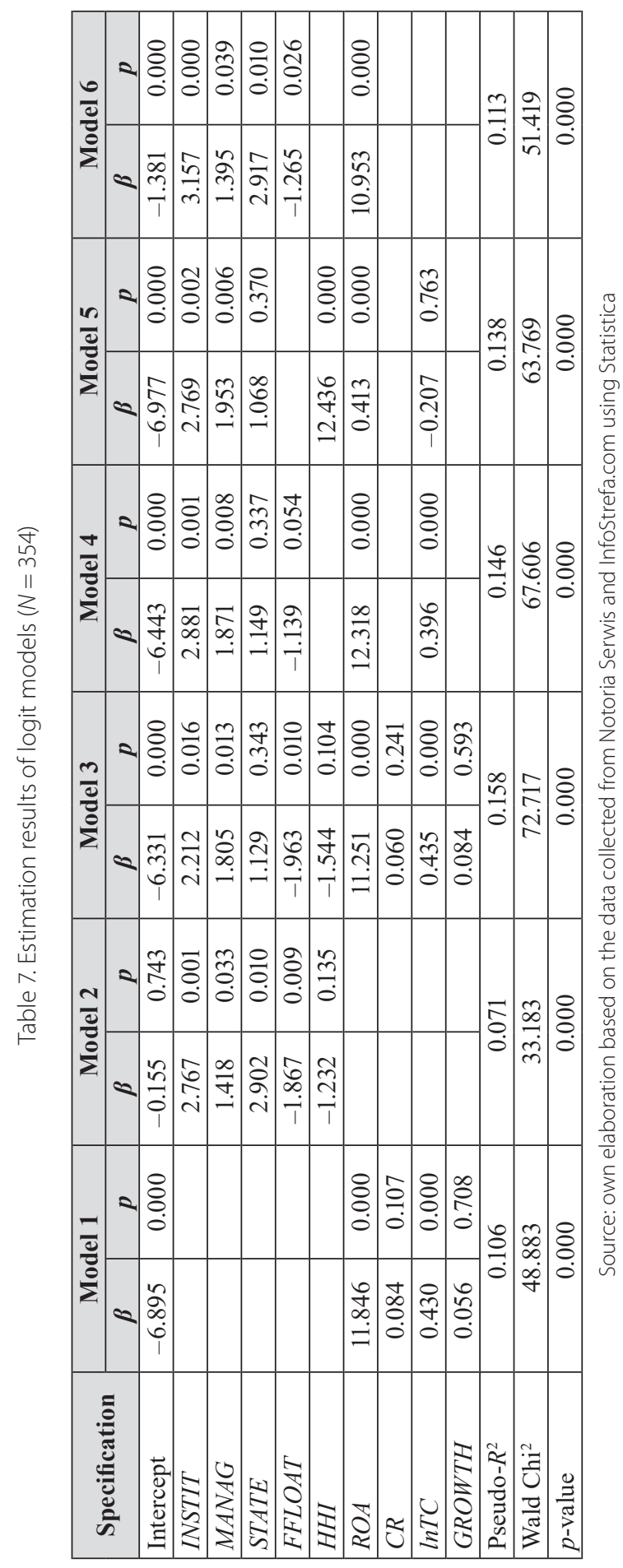


The estimation results of tobit models are presented in Table 8 . They indicate the existence of statistically significant relationship between the share of institutional investors in the ownership structure and the amount of dividend pay-out. The value of parameter for INSTIT is positive and ranges from 2.123 to 2.873 , which means that along with an increase of $1 \%$ in the number of votes of the institutional investors, approx. $2.1-2.9 \%$ more of earnings is paid out as a dividend. Considering the variable $M A N A G$, it should be noted that an increase in managerial ownership positively affects the amount of dividend. However, the parameter values for this variable are much lower than those for the variable INSTIT and statistically significant only in Model 4 and Model 5 (0.940 and 1.061, respectively). Therefore, it can be said that an increase of $1 \%$ in managerial ownership results in an increase of $1 \%$ in the dividend pay-out ratio. The parameter values for STATE are also positive, however, in most of the models, they are not statistically significant. The statistical significance of parameter is observed only in Model 2 (at $\alpha=0.1$ ). In this model, an increase in the share of the State Treasury of $1 \%$ results in an increase in the dividend pay-out of approx. 1.4\%. In turn, the parameter values for FFLOAT are negative in each of five models with this variable. Along with an increase of $1 \%$ in the share of votes of minority shareholders, $2 \%$ less of earnings is paid out. In turn, the values of parameter for $H H I$ are negative and statistically significant in Model 3 and Model 6 (-1.388 and -1.565 , respectively). On the basis of data presented in Tables 7 and 8 , it can be concluded that, on the one hand, an increase in ownership concentration results in the higher propensity to pay a dividend, but on the other hand, it results in the lower amount of dividend pay-out.

Also, the dividend depends on the profitability of the company. The value of parameter for $R O A$ is positive and the highest in all models. An increase in return on assets of $1 \%$ resulted in an increase in dividend pay-out of approx. 4.6-5.5\%. What is more, the parameter values for $\ln T C$ are also positive and statistically significant in all models with this variable (they range from 0.299 to 0.331 ), which indicates that large companies spend more earnings on dividend. In turn, the value of parameter for $C R$ is positive and statistically significant only in Model 1, while the values of parameter for GROWTH are not significant (see Table 8). 


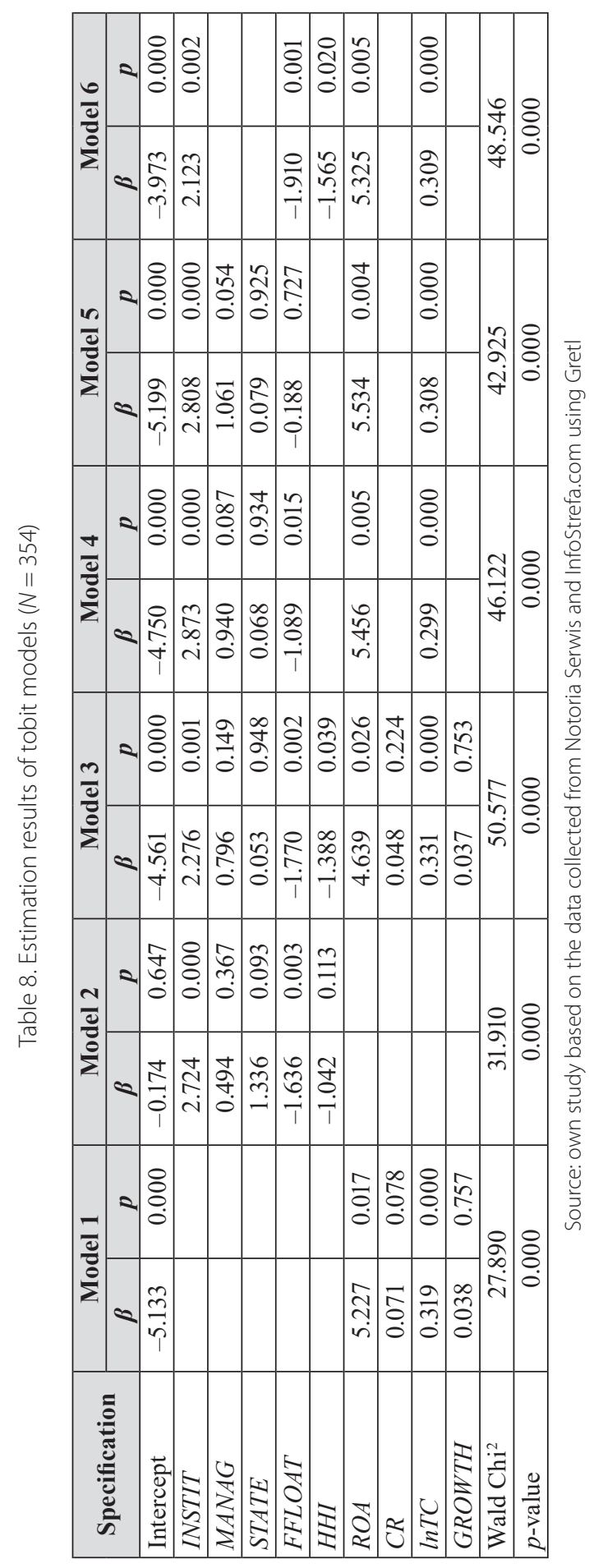




\section{Conclusions}

The survey conducted on non-financial companies shows the existence of links between ownership concentration and dividend pay-out. The highest average amount of dividend pay-out is observed in the case of companies in which the greatest number of votes belong to institutional investors. The research confirms that institutional investors prefer to invest in dividend companies. High dividends are also paid out by companies in which the largest shareholder is the State Treasury, for which the dividend is one of the budget revenues. Moreover, a high average amount of dividend pay-out is observed in companies with highly concentrated managerial ownership. It seems that in such a case the aim of dividend pay-out is to mitigate the agency conflict and make managers' goals become convergent with shareholders' goals. In turn, the lowest dividend is paid by companies in which ownership is highly dispersed. This confirms the limited decision-making and control capacity of minority shareholders.

The analyses conducted using regression models show that along with an increase in the share of institutional investors, dividend decisions are made more often, and the amount of dividend pay-out increases. Also, an increase in the state and managerial ownership positively affects the propensity to pay a dividend as well as the amount of dividend pay-out. The opposite situation occurs in the case of companies with highly dispersed ownership. Along with the increase in the share of minority shareholders, the propensity to pay a dividend decreases and the dividend level is lower. While examining the degree of ownership concentration, it should be noted that the increase in ownership concentration is conducive to the decision to pay dividends (a dividend is paid out more frequently), however the amount of dividend is lower.

\section{References}

Adamska A. (2012), Zmiany akcjonariatu spółek publicznych w dobie kryzysu, "Studia i Prace Kolegium Zarządzania i Finansów", vol. 117, pp. 36-53.

Adjaoud F., Hermassi N. (2017), The Impact of Corporate Governance Mechanisms on the Dividend Policy of Canadian Firms: Empirical Study, "International Journal of Business, Accounting and Finance", vol. 11, no. 1, pp. 90-105.

Aluchna M. (2007), Mechanizmy corporate governance w spótkach giełdowych, Szkoła Główna Handlowa w Warszawie - Oficyna Wydawnicza, Warszawa.

Baker M., Wurgler J. (2004), Appearing and Disappearing Dividends: the Link to Catering Incentives, "Journal of Financial Economics", vol. 73, no. 2, pp. 271-288, http://dx.doi.org/10.1016/j. jfineco.2003.08.001

Bohdanowicz L. (2016), Własność menedżerska w polskich spółkach publicznych, Wydawnictwo Uniwersytetu Łódzkiego, Łódź.

DeAngelo H., DeAngelo L. (2007), Payout Policy Pedagogy: What Matters and Why, "European Financial Management", vol. 13, pp. 11-27, http://dx.doi.org/10.1111/j.1468-036X.2006.00283.x 
Dębski W. (2007), Rynek finansowy i jego mechanizmy. Podstawy teorii i praktyki, Wydawnictwo Naukowe PWN, Warszawa.

Eije H., Megginson W.L. (2008), Dividends and Share Repurchases in European Union, "Journal of Financial Economics", vol. 89, no. 2, pp. 347-374.

Fisher K.L., Statman M. (2000), Cognitive Biases in Market Forecast, "Journal of Portfolio Management", vol. 27, no. 1, pp. 72-81, http://dx.doi.org/10.3905/jpm.2000.319785

Florackis C., Kanas A., Kostakis A. (2015), Dividend policy, managerial ownership and debt financing: A non-parametric perspective, "European Journal of Operational Research", vol. 241, pp. 783-795, http://dx.doi.org/10.1016/j.ejor.2014.08.031

French D. W., Varson P.L., Moon K.P. (2005), Capital Structure and the Ex-Dividend Day Return, "The Financial Review", vol. 40, pp. 361-379, http://dx.doi.org/10.1111/j.1540-6288.2005.00106.x

Grullon G., Michaelly R., Benartzi S., Thaler R.H. (2005), Dividend Changes Do Not Signal Changes in Future Profitability, "Journal of Business", vol. 78, no. 5, pp. 1659-1682, http://dx.doi. org/10.1086/431438

Jacob M., Jacob M. (2013), Taxation, Dividends and Share Repurchases: Taking Evidence Global, "Journal of Financial and Quantitative Analysis", vol. 48, no. 4, pp. 1241-1269, http://dx.doi. org/10.1017/S0022109013000367

Kaźmierska-Jóźwiak B. (2016), Struktura własności a skłonność do wypłaty dywidendy, "Finanse, Rynki Finansowe, Ubezpieczenia", vol. 4, no. 82, pp. 171-178, http://dx.doi.org/10.18276/ frfu.2016.4.82/2-13

Khan T. (2006), Company Dividends and Ownership Structure: Evidence from UK Panel Data, "The Economic Journal", vol. 116, pp. 172-189, http://dx.doi.org/10.1111/j.1468-0297.2006.01082.x

Kufel T. (2009), Ekonometria. Rozwiazywanie problemów z wykorzystaniem program GRETL, Wydawnictwo Naukowe PWN, Warszawa.

Lace N., Bistrova J., Kozlovskis K. (2013), Ownership Type Influence on Dividend Payments in CEE Countries, "Business: Theory and Practice", vol. 14, no. 3, pp. 259-266, http://dx.doi. org/10.3846/btp.2013.27

Liljeblom E., Maury B. (2016), Shareholder Protection, Ownership, and Dividends: Russian Evidence, "Emerging Markets Finance \& Trade", vol. 52, pp. 2414-2433, http://dx.doi.org/10.10 80/1540496X.2015.1073991

Mancinelli L., Ozkan A. (2006), Ownership Structure and Dividend Policy: Evidence From Italian Firms, "The European Journal of Finance", vol. 12, no. 3, pp. 265-282, http://dx.doi. org/10.1080/13518470500249365

Pieloch-Babiarz A. (2017), Wypłata dywidendy w spółkach z rozproszona własnościa, "Przegląd Organizacji”, vol. 6, pp. 29-36.

Short H., Zhang H., Keasey K. (2002), The Link Between Dividend Policy and Industrial Ownership, "Journal of Corporate Finance", vol. 8, pp. 105-122.

Smith D.D., Pennathur A.K., Marciniak M.R. (2017), Why do CEOs agree to the discipline of dividends?, "International Review of Financial Analysis", vol. 52, pp. 38-48, http://dx.doi. org/10.1016/j.irfa.2017.04.010

Stanisz A. (2007), Przystępny kurs statystyki z zastosowaniem STATISTICA PL na przykładach z medycyny. Tom 2, StatSoft, Kraków.

Wawryszuk-Misztal A. (2016), Zmiany w strukturze akcjonariatu polskich spółek giełdowych zmieniajacych rynek notowań akcji, "Acta Universitatis Lodziensis. Folia Oeconomica”, vol. 4, no. 323 , pp. $141-153$,

Wypych M. (2015), Koncentracja własności a wypłata dywidendy na przykładzie przemysłowych spółek giełdowych, "Finanse, Rynki Finansowe, Ubezpieczenia", vol. 73, pp. 783-792. 


\section{Zróżnicowana struktura własności a wypłata dywidendy przez spółki giełdowe}

Streszczenie: Celem artykułu jest zidentyfikowanie i scharakteryzowanie relacji między strukturą własności spółek publicznych a realizacją wypłaty dywidendy. Hipoteza badawcza stanowi, iż wraz ze wzrostem stopnia koncentracji własności wzrasta zarówno skłonność do wypłaty dywidendy, jak i jej wysokość. Badania przeprowadzone zostały na grupie 354 spółek niefinansowych notowanych na Giełdzie Papierów Wartościowych w Warszawie. Zasadniczą metodą badawczą była analiza regresji logistycznej i tobitowej. Przeprowadzone badania wykazały, że wraz ze wzrostem w strukturze własności udziału Skarbu Państwa, inwestorów instytucjonalnych i członków zarządu, decyzje o wypłacie dywidendy zapadały częściej, a wysokość wypłaty wzrastała. Analizując stopień koncentracji własności wyrażony indeksem Herfindahla-Hirschmana, uzyskano zróżnicowane wyniki badań. Estymacja niektórych modeli regresji wykazała, iż silniejsza koncentracja własności sprzyjała podjęciu decyzji o wypłacie dywidendy (dywidendy wypłacane były częściej), jednakże wraz ze wzrostem stopnia koncentracji własności wysokość dywidendy malała. Przedstawione w artykule wyniki badań stanowią uzupełnienie dotychczasowych analiz prowadzonych na rynkach światowych i są rozszerzeniem dotychczasowych badań prowadzonych na GPW w Warszawie.

Słowa kluczowe: polityka dywidendy, struktura akcjonariatu, własność menedżerska, własność instytucjonalna, własność Skarbu Państwa, GPW w Warszawie

JEL: G11, G18, G35

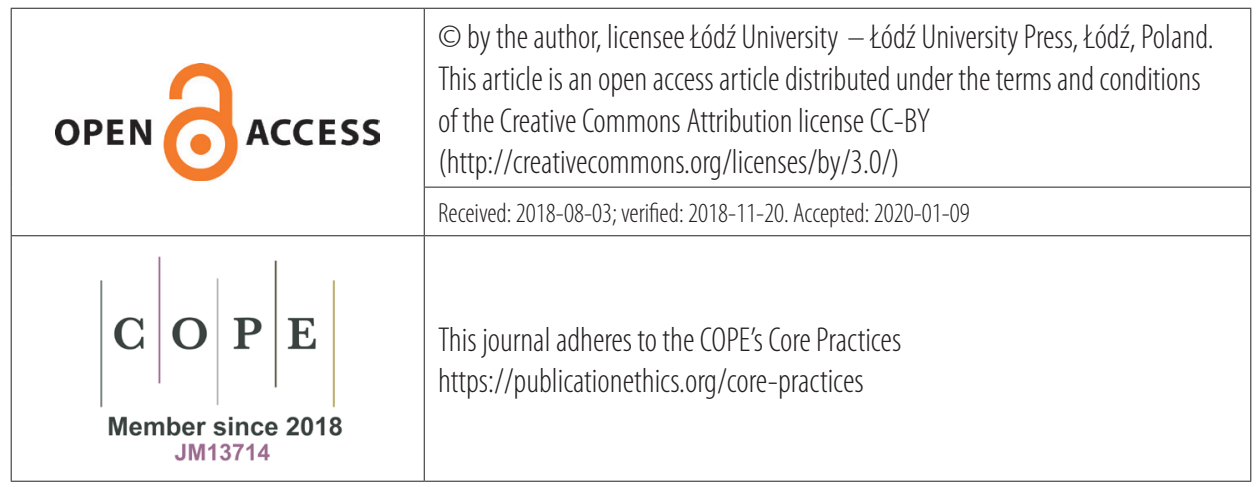

